\title{
Color Key
}
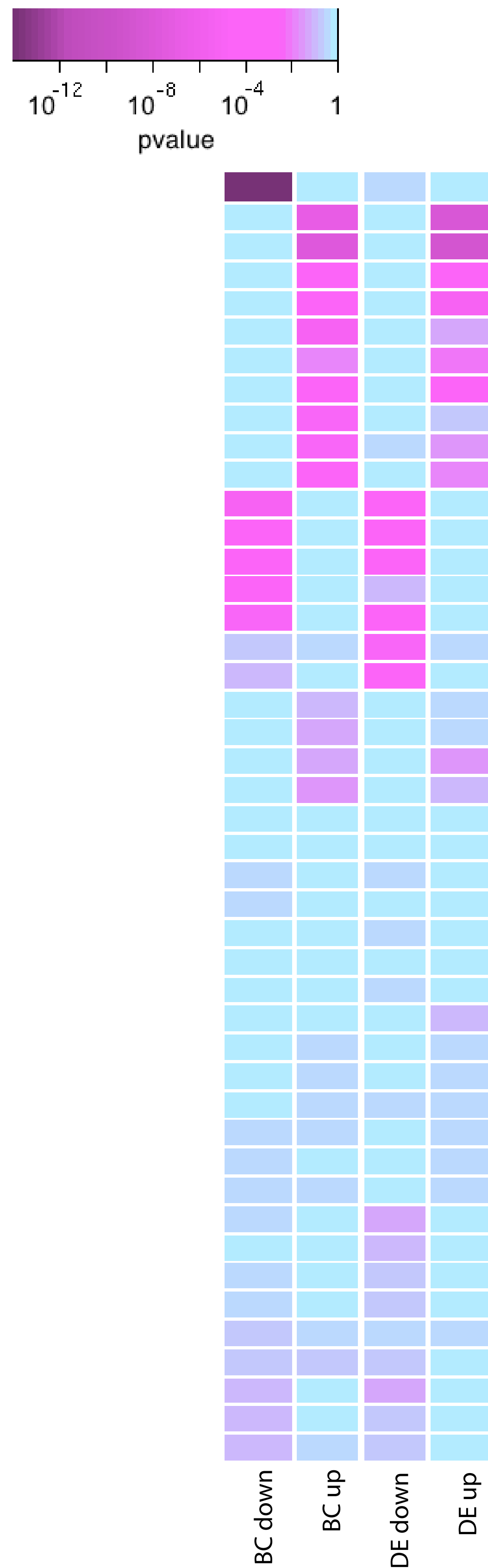

Ribosome

Protein kinase

Cytoskeleton

GRESAG

Mitochondrial DNA

RNA helicase

DNA synthesis, modification, repair

LRRP

rRNA-tRNA processing

Nucleo-cytoplasmic transport

Signalling

Mitochondrial electron transport

Chaperone

Mitochondrial pathway

Redox pathways

RNA processing

Vesicular transport

Mitochondrial translation

Translation

translation tRNA

Transporter

Ion channel or pump

Ubiquitin/proteasome

rRNA tRNA processing

Cytoskeleton_Actin

RNA synthesis III

Acidocalcisome

GPI anchors \& metabolism

Zinc finger

RNA binding

Glycosome biogenesis

Protein phosphatase

RNA degradation

Chromatin

Nucleotides

Cell cycle

Oxidative phosphorylation

Amino acid metabolism

Mitochondrial biogenesis

Enzyme

Lipids \& fatty acids

Lysosome

Mltochondrial membrane

Calcium

RNA synthesis II 